\title{
The Correction of Facial Morphea Lesions by Hyaluronic Acid: A Case Series and Literature Review
}

\author{
Agnieszka Owczarczyk-Saczonek • Marta Kasprowicz-Furmańczyk • \\ Anna Kruszewska • Magdalena Krajewska-Włodarczyk • \\ Agata Bechtold (D) P Paulina Klimek · Waldemar Placek
}

Received: July 10, 2020 / Published online: September 2, 2020

(C) The Author(s) 2020

\begin{abstract}
Introduction: The aim of the study is to assess the long-term safety and efficacy of hyaluronic acid (HA) administration in correction of facial morphea lesions and to review the literature on the subject. Morphea is a chronic inflammatory disease of the connective tissue which may lead to serious deformations. The lesions located on the face particularly affect patients' quality of
\end{abstract}

Digital Features To view digital features for this article go to https://doi.org/10.6084/m9.figshare.12807083.

A. Owczarczyk-Saczonek · M. KasprowiczFurmańczyk · A. Kruszewska · A. Bechtold (ه) .

P. Klimek · W. Placek

The Chair and Clinic of Dermatology, Sexually

Transmitted Diseases and Clinical Immunology,

The Municipal Polyclinical Hospital in Olsztyn,

Olsztyn, Poland

e-mail: aganek@wp.pl;

agata.bechtold@umed.lodz.pl

M. Krajewska-Włodarczyk

Department of Rheumatology, The Municipal

Polyclinical Hospital in Olsztyn, Olsztyn, Poland

M. Krajewska-Włodarczyk

Department of Internal Medicine, School of

Medicine, Collegium Medicum, University of

Warmia and Mazury, Olsztyn, Poland

A. Bechtold

Psychodermatology Department, Medical

University of Lodz, Łódź, Poland life and self-esteem; thus, there is a demand for safe and effective methods of treatment.

Case Presentation: The paper presents three female patients aged 16, 17 and 70 with facial morphea lesions who had HA preparation Juvéderm $^{\circledR}$ Voluma or Volux, Vycross ${ }^{\circledR}$ technology, Allergan, injected. One of the patients had additionally fractional ablative $\mathrm{CO}_{2}$ laser (FAL) therapy.

Discussion: The literature provides reports on successful use of HA, polymethylmethacrylate and poly-L-lactic acid for the correction of facial defects in localized scleroderma. HA is a natural component of the extracellular matrix and it therefore minimizes the probability of immunogenicity. The application technique also plays an important role. On the other hand, FAL therapy leads to the degradation of the abnormal collagen and the induction of normal collagen synthesis.

Conclusions: HA injection and combination of HA application with FAL are minimally invasive, effective and safe therapeutic options for patients suffering from morphea.

Keywords: Correction; FAL; Fractional ablative laser; Hyaluronic acid; Morphea; Scleroderma 


\section{Key Summary Points}

Why carry out this study?

Morphea is a chronic inflammatory disease of connective tissue leading to deformations of the involved region, including face, thus causing significant lowering of patients' quality of life

Existing therapeutic methods focus on silencing active process, ignoring the deformities the patients' are left with

The study aimed at assessment of longterm safety and efficacy of hyaluronic acid (HA) administration in correction of facial morphea lesions

\section{What was learned from the study?}

The combination of HA injection and FAL is a minimally invasive, effective and safe therapeutic option for patients suffering from morphea

In some cases it may be beneficial to complement the therapy with fractional ablative $\mathrm{CO}_{2}$ laser

If promising results are further confirmed, the method should be widely recommended for correction of the defects produced by morphea

\section{DIGITAL FEATURES}

This article is published with digital features to facilitate understanding of the article. You can access the digital features on the article's associated Figshare page. To view digital features for this article go to https://doi.org/10.6084/m9. figshare.12807083.

\section{INTRODUCTION}

Morphea (localized scleroderma, LoSc) is a chronic inflammatory disease of connective tissue which presents with a wide spectrum of clinical symptoms depending on the activity of the disease, involved region and the depth of the lesions. The lesions most often affect dermis and subcutaneous tissue and show tendency for spontaneous remission, yet causing skin atrophy and dyspigmentation [1]. Less often the process affects deeper tissues (fascia, muscles and bones), leading to deep atrophy and deformations. The excessive synthesis of collagen type I and III and extracellular components is regarded to play the key role in the formation of characteristic skin lesions [2].

The etiopathogenesis of this condition is still not clear. The genetic and environmental factors, as well as microchimerism, are considered to activate keratinocytes to release inflammatory mediators (interleukin-4 (IL-4), IL-6, IL-10, IL-17A, IL-27, interferon- $\gamma$ ), which subsequently stimulate lymphocytes, endothelial cells and fibroblasts. Of particular significance, the activation of endothelial cells and lymphocytes provokes fibroblasts to increase collagen synthesis, which clinically manifests as focal skin hardening and active inflammatory border (lilac ring) [1-4].

Despite the suggestions of developmental origins of morphea (due to frequent pattern of lesions alongside Blaschko's lines), numerous evidence confirms its autoimmune background (the correlation with personal and family history of autoimmune diseases, the presence of human leukocyte antigen (HLA) class II molecules found also in other autoimmune disorders) [1].

The facial lesions lead to the deformation of the face, lowering patients' quality of life, especially in adults $[5,6]$. It is most pronounced in en coup de sabre type, which is characterized by linear atrophy and hardening of the skin, subcutaneous tissue, muscles and bones, usually extending from the upper limit of the eyebrow to the scalp, often with concomitant alopecia and eyebrow loss [1]. The therapeutic options proposed by consensuses aim at silencing active 
forms, hindering the progression of the disease, but usually they do not discuss methods of correction of the defects generated by the lesions [1, 7-9].

The literature provides reports on correction of facial defects in localized scleroderma (morphea, en coup de sabre, hemiatrophia faciei Parry-Romberg) using hyaluronic acid (HA) [10-12], polymethylmethacrylate [13], poly-Llactic acid [14] and autologous fat [15-17] performed successfully and with no delayed type hypersensitivity.

The aim of the study is to assess the longterm safety and efficacy of HA administration in correction of facial morphea lesions. This article presents our experience on the subject. In this paper we present case series of three female patients with morphea, who had their lesions corrected by HA. In one of the patients, the aforementioned procedure was combined with fractional carbon dioxide laser (FAL) therapy. All the patients have had contraindications to fillers excluded (active infection, allergy/hypersensitivity to the filler and lignocaine, unstable autoimmune disease) [18]. After informed consent was obtained, HA preparation Juvéderm $^{\circledR}$ Voluma or Volux, Vycross ${ }^{\circledR}$ technology, manufactured by Allergan, was administered. The patients gave informed consent to participate in the study and for the publication of the results. The patients were examined every second week, without observing any adverse reactions (observation time ranged from 6 months to 3 years) and achieving patients complete satisfaction with the correction of the defect. The result was described with the Localized Scleroderma Damage Index (LoSDI), part of the Localized Scleroderma Assessment Tool (LoSCAT). LoSDI assesses dermal atrophy (DAT), subcutaneous atrophy (SAT) and dyspigmentation (DP) ranging from 0 to 3 in each domain, with 9 points in total indicating the most severe skin damage.

\section{CASE 1}

In this 17-year-old female patient a linear induration of the skin with subcutaneous tissue atrophy located on the forehead from the eyebrows to the scalp and accompanying scarring (cicatricial) alopecia and partial hair loss within the eyebrows and the eyelashes were observed. After a few months of the disease a similar linear atrophic lesion was noticed in the left frontoparietal region. The histopathologic examination revealed preserved skin appendages, the epidermis with no tangible abnormalities, the homogenization of the subepidermal layer of the dermis and noticeable concentration of elastic fibres on orcein staining. On the basis of the clinical presentation and histopathological examination, limited scleroderma en coup de sabre was diagnosed. The patient had no personal history of chronic diseases and no family history of autoimmune disorders. The laboratory results showed an increased level of anti-thyroid peroxidase antibodies $(286 \mathrm{IU} / \mathrm{ml})$ with normal level of thyroid stimulating hormone and also elevated ANAHep2 titre 1:1280 (negative immunoblotting). Antibodies IgG and IgM against Borrelia burgdorferi were negative. The patient was consulted by a neurologist and ophthalmologistno notable abnormalities were discovered. Magnetic resonance imaging (MRI) was performed to exclude anomalies of the central nervous system and did not shown any significant changes (in the white matter of the right cerebellar hemisphere at the posterior-lateral outline of IV ventricle a small band with increased signal in FLAIR, T2, PD-gliosis? $5 \mathrm{~mm}$; other brain structures, ventricular system and basal cisterns were normal). The X-ray of the skull presented normal structure. Treatment with methylprednisolone $4 \mathrm{mg}$ a day was applied, yet as a result of the progression of skin lesions the dose was increased to $16 \mathrm{mg}$ daily and additionally mofetil mycophenolate $1 \mathrm{~g}$ a day was introduced.

Six months after a stabilization of the disease, the patient had HA agent injected into morphea lesions. The initial LoSDI score was 7 (DAT 3, SAT 3, DP 1). To avoid potential complications of administering excessive amounts of the medication and following compression of arterial vessels in the frontal region, where the amount of subcutaneous tissue is limited, initially only $0.5 \mathrm{ml}$ was injected into each side of the induration and skin depression from above 

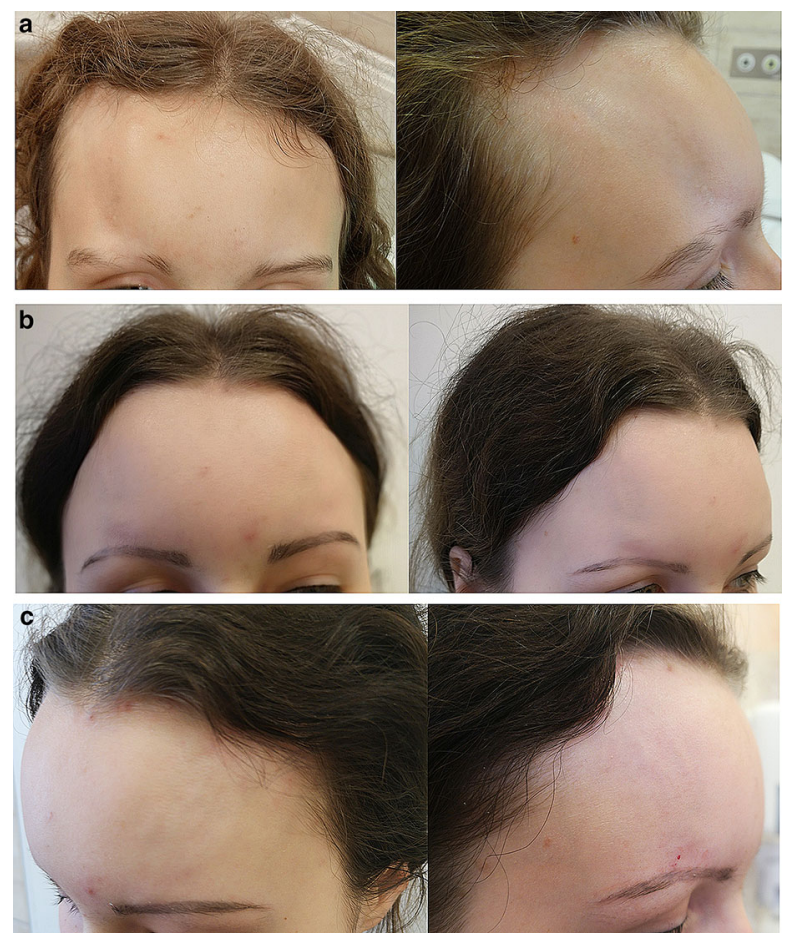

Fig.1 The effect before the treatment (a), after the first intervention (b) and the final result (c)

the eyebrow up to the hairline. The injection was performed without anaesthesia using a $25 \mathrm{G}$ cannula inserted into subcutaneous tissue with the needle deep on the bone surface. Partial shallowing of the lesions was achieved. After a week, the procedure was repeated, also using 0.5-ml portions of HA, but with a 30G needle and in the form of boluses (each injection preceded by an aspiration). A very good aesthetic effect was obtained which is reflected by the LoSDI 3 (DAT 1, SAT 1, DP 1) and can be seen in the photographs (Fig. 1a-c).

Within 1.5 years after the intervention no progression has occurred. The patient was on mofetil mycophenolate $1 \mathrm{~g}$ a day and methylprednisolone in gradually reduced doses up to $2 \mathrm{mg}$ every second day. After 1.5 years slight reduction in volume of administered HA has led to the decision to repeat the procedure. The filling within both morphea lesions with $0.5 \mathrm{ml}$ of HA per side ( $25 \mathrm{G}$ cannula) produced an outcome satisfactory for the patient. After the procedure, a gradual reduction of the dose of immunosuppressants has taken place. The

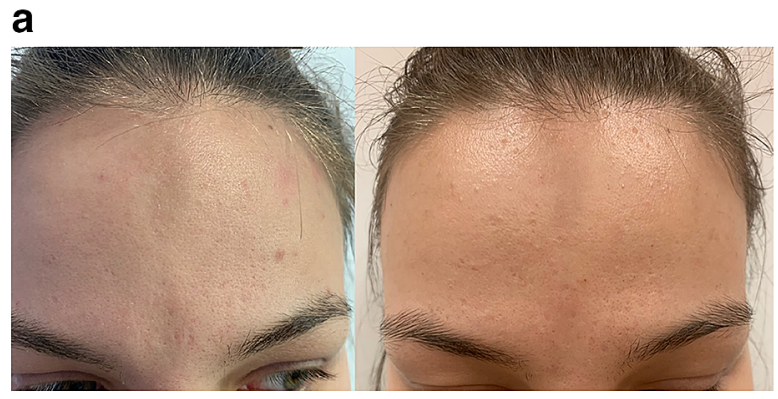

b

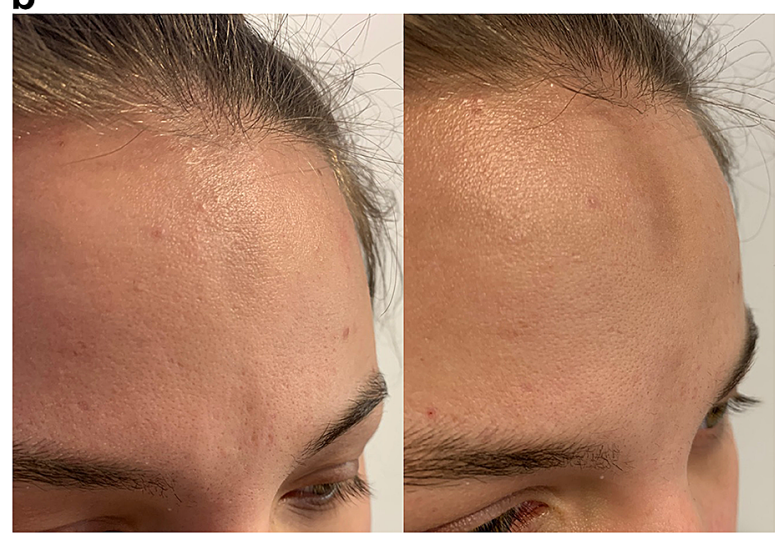

Fig. 2 The patient before and a week after the injection of Voluma $1 \mathrm{ml}$, via $27 \mathrm{G}$ cannula - front view (a) and side view $(\mathbf{b})$

follow-up lasted for 8 months after the reduction of the dose of mofetil mycophenolate up to $500 \mathrm{mg}$ per day and 6 months after discontinuation of the drug - a desirable aesthetic result and no progression of morphea lesions were observed.

\section{CASE 2}

A 16-year-old female reported to the hospital because of numerous skin lesions located on the trunk (occurred approximately 1 year before admission) and on the face (appeared 2 months before hospitalization). The patient had no record of chronic diseases and no family history of autoimmune disorders. Physical examination revealed flat, oval, silvery, porcelain lesions a few centimetres in size with a discrete violaceous erythema "lilac ring" on the circumference of the lesion and palpable induration located on the trunk, mainly on the back. On the forehead along the medial line from the 
glabella up to the hairline the lesion presented as linear, bifocal dyspigmentation with a discrete depression alongside (Fig. 2a, b).

Both laboratory results and medical imaging have not revealed any significant abnormalities. ANA-Hep2-1:160, antibodies against B. burgdorferi IgM and IgG were negative. On the basis of the clinical manifestation and histopathological examination limited scleroderma was diagnosed (morphea).

During hospitalization procaine penicillin 1.2 million IU, PUVA therapy, Piascledine and tacrolimus $0.1 \%$ were applied, which led to an improvement-the disappearance of "lilac ring" and the discontinuation of the emergence of new lesions.

Six months after the stabilization of the disease, on obtaining informed consent, the patient underwent a correction of morphea lesion on the forehead with the use of HA. Thus, $0.5 \mathrm{ml}$ of the filler was injected without anaesthesia into each region of induration and skin depression from the glabella up to the hairline with a $27 \mathrm{G}$ cannula inserted into subcutaneous tissue with the needle deep on the bone surface. The LoSDI was lowered from 5 (DAT 2, SAT 2, DP 1) to 3 (DAT 1, SAT 1, DP 1).

\section{CASE 3}

A 70-year-old female patient reported to our dermatology clinic as a result of disseminated granuloma annulare lesions for 6 months. Besides, she suffered from hypertension and as a teenager she developed morphea of the face. This year in June the patient underwent

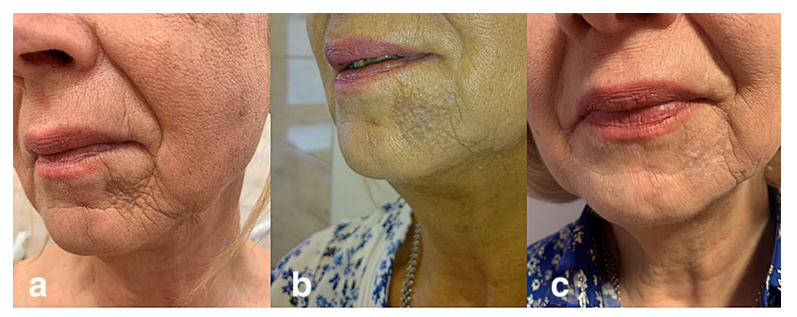

Fig. 3 Patient no. 3: a month after $1 \mathrm{ml}$ of Voluma ${ }^{\circledR}$ injection (a); after a series of three FAL therapies and 2 weeks after Volux injection (b); 6 months after correction (c) treatment with doxycycline and cefuroxime as a result of borreliosis (positive IgM and IgG antibodies against $B$. burgdorferi). By this time her skin lesions were treated only topically without success.

Physical examination revealed diffused cohesive, well-demarcated, pale red papules with circular palpable borders on the upper limbs, lower abdomen and hips. Additionally, on the left side of the chin the patient had an extensive atrophic scar $3 \times 3 \mathrm{~cm}$ in size, a remnant of prior deep morphea (Fig. 3a). The LoSDI was assessed to be 5 (DAT 2, SAT 2, DP 1).

On the basis of histopathological examination granuloma annulare was diagnosed (the presence of minor infiltration consisting of $\mathrm{CD} 8^{+}$histiocytes and $\mathrm{CD}^{+}$lymphocytes, $\mathrm{CD} \mathrm{a}^{+}$and $\mathrm{S}-100^{+}$Langerhans cells in small clusters). The laboratory results and imaging did not show any significant abnormalities.

During the hospitalization the patient was treated topically with mometasone and also by UVB $311 \mathrm{~nm}$ phototherapy, obtaining substantial improvement regarding skin lesions associated with granuloma annulare.

The correction of the morphea lesion was performed with a 1.0-ml bolus of HA agent, injected into subcutaneous tissue without anesthesia with a 30G needle, obtaining significant shallowing of the lesion (Fig. 3b). The image of the filling was captured by skin ultrasonography (Fig. 4a, b). The patient was discharged from the hospital with recommendations to continue previous treatment.

On physical examination during the followup, it was decided to incorporate FAL treatment. The procedure was applied monthly, three times in total (power $23 \mathrm{~W}$, microbeam spacing $1400 \mu \mathrm{m}$, energy density $28 \mathrm{~mJ} / \mathrm{cm}^{2}$; Metrum, Cryoflex, Poland). As a result of the partial resorption of HA, half a year after the first injection, $1 \mathrm{ml}$ of a more cross-linked HA agent $\left(\right.$ Volux $\left.^{\circledR}\right)$ was applied. After 2 weeks it was followed by an application of $1 \mathrm{ml}$ of less crosslinked HA, observing a very good cosmetic effect (Figs. 3c, 4c). It resulted in lowering the LoSDI score to 1 (DAT 1, SAT 0, DP 0). 

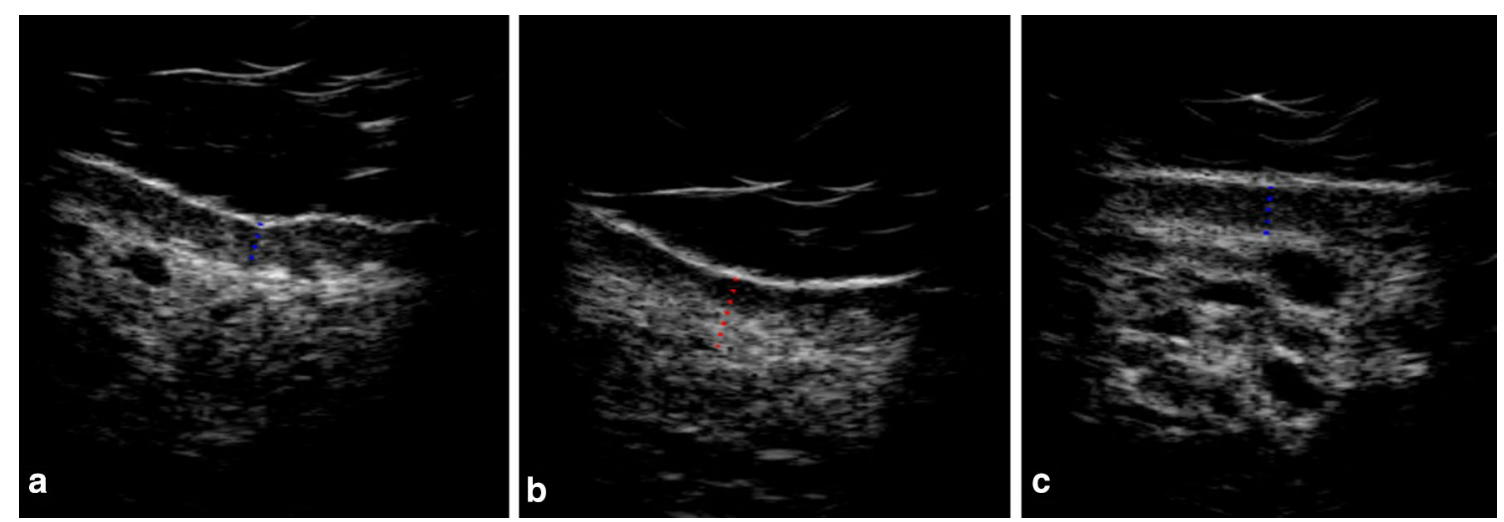

Fig. 4 Ultrasound examination of the lesion. The lesion before the treatment: local atrophy of subcutaneous tissue and skin thinning (a); 1 week after first FAL treatment: oedema of the dermis, no significant alteration in subcutaneous tissue thickness (b); the lesion after two FAL treatments and HA injection: visible HA deposits in subcutaneous tissue, an increase in skin thickness

\section{DISCUSSION}

The application of fillers in correction of morphea, an autoimmune disease, raises many doubts and causes the fear of provocation of inflammation and recurrence of the disease. Therefore, surgical procedures should be performed during the inactive stage of the disease to minimize the risk of relapse $[9,19]$. The current consensus of world experts has not named an absolute contraindication to the use $\mathrm{HA}$ in the case of scleroderma and other autoimmune diseases [20].

A perfect agent for the injection should be non-immunogenic, biocompatible and stable in the site of an implantation with minimal risk of complications. The cross-linked HA is the closest to this ideal with its decreased rate of degradation and high water absorption, and therefore can be a useful substance to correct even substantial skin defects $[21,22]$.

HA is a natural glycosaminoglycan component of the extracellular matrix. Its main advantage is the identical structure of the molecule in any living being, which minimizes the probability of immunogenicity [21, 22]. So far, no single case of reactivation or stimulation of morphea was reported after administration of compared to before the treatment $(0.79 \mathrm{~mm})$ and noticeable skin resmoothing (filling of the defect) (c). Morphological skin lesions were examined with DermaMed equipment and software (DRAMIŃSKI, Olsztyn, Poland) with a linear head of a frequency $48 \mathrm{MHz}$. In order to avoid exerting pressure on surface tissues, an appropriate amount of gel (without gel pads) was used

purified HA biosynthesized via bacterial fermentation [15]. The widespread use of HA in orthopaedics for intra-articular injections for many years serves as evidence of its safety profile [23].

The remodelling of skin lesions in our patients was performed with Voluma, which is a composition of low molecular weight $(<1 \mathrm{MDa})$ and high molecular weight $\mathrm{HA}$ ( $>1 \mathrm{MDa}$ ), producing a mobile network with advantageous structural properties. It possesses also unique rheological properties: high elastic modulus $G^{\prime}$ and low swelling ratio, determining its ability to return to the initial shape with a slight change in implant volume after its application. The durability of the filling may be up to 24 months [24]. In one of the cases Volux was used to prolong the effect of the procedure.

Even though the usage of HA in morphea appears to be safe, the procedure is performed with great caution and the number of available case reports in the literature is still very limited (Table 1). The longest observation of the highest number of patients was reported by Sharquie et al. They performed the procedure twice in each of the 16 patients with morphea using Neauvia Organic gel. The study lasted from 2008 until 2019 and none of the subjects suffered from a relapse of the disease or any other 
Table 1 Usage of HA in morphea

\begin{tabular}{|c|c|c|c|c|c|}
\hline Author & $\begin{array}{l}\text { Subtype of } \\
\text { morphea }\end{array}$ & $\begin{array}{l}\text { HA } \\
\text { product }\end{array}$ & Technique & $\begin{array}{l}\text { Additional } \\
\text { methods }\end{array}$ & Follow-up \\
\hline $\begin{array}{l}\text { Kerdel and } \\
\text { Skopit } \\
{[25]}\end{array}$ & $\begin{array}{l}\text { En coup de } \\
\text { sabre }\end{array}$ & $\begin{array}{l}\text { Juvederm } \\
\text { Ultra Plus } \\
\text { XC }\end{array}$ & $\begin{array}{l}0.7 \mathrm{ml} \text { injected above the } \\
\text { periosteum and throughout } \\
\text { the linear defect with a } 27 \mathrm{G} \\
\text { needle }\end{array}$ & No & $\begin{array}{l}0.5 \mathrm{ml} \text { injected after } \\
6 \text { weeks; } 6 \text { months after a } \\
\text { good effect was still } \\
\text { observed }\end{array}$ \\
\hline $\begin{array}{l}\text { Choksi and } \\
\text { Orringer } \\
{[11]}\end{array}$ & $\begin{array}{l}\text { En coup de } \\
\text { sabre }\end{array}$ & $\begin{array}{l}1 \mathrm{ml} \\
\text { Perlane }\end{array}$ & $\begin{array}{l}\text { A linear threading technique, } \\
\text { with an } 75 \% \text { improvement }\end{array}$ & No & $\begin{array}{l}\text { Effect sustained for at least } \\
5 \text { months, after repeat } \\
\text { injection of } 1 \mathrm{ml} \text { of HA } \\
\text { was given with } 90 \% \\
\text { improvement }\end{array}$ \\
\hline $\begin{array}{l}\text { Thareja } \\
\text { et al. [12] }\end{array}$ & $\begin{array}{l}\text { En coup de } \\
\text { sabre }\end{array}$ & $2 \mathrm{ml} \mathrm{HA}$ & ? Intradermal & No & $\begin{array}{l}\text { Further injections } 6 \text { months } \\
\text { after with improvement }\end{array}$ \\
\hline $\begin{array}{l}\text { Mashiko } \\
\text { et al. [26] }\end{array}$ & $\begin{array}{l}\text { En coup de } \\
\text { sabre }\end{array}$ & $\begin{array}{l}1.0 \mathrm{ml} \\
\text { Restylane }\end{array}$ & $\begin{array}{l}\text { Injection below the periosteum } \\
\text { for osteoinduction from the } \\
\text { underlying bone-a sharp } \\
\text { needle ( } 30 \text { to } 34 \mathrm{G} \text { ) with } \\
\text { overcorrection } 10-20 \%\end{array}$ & No & Effect up to 12 months \\
\hline $\begin{array}{l}\text { Sivek and } \\
\text { Emer } \\
{[27]}\end{array}$ & $\begin{array}{l}\text { En coup de } \\
\text { sabre }\end{array}$ & $\begin{array}{l}0.8 \mathrm{ml} \\
\text { Juvederm } \\
\text { Ultra Plus }\end{array}$ & $\begin{array}{l}\text { A blunt-tipped microcannula } \\
(25 \mathrm{G})\end{array}$ & No & $\begin{array}{l}\text { Effect maintained for more } \\
\text { than } 9 \text { months }\end{array}$ \\
\hline $\begin{array}{c}\text { Arsiwala } \\
{[10]}\end{array}$ & $\begin{array}{l}\text { Morphea } \\
\text { involving the } \\
\text { chin }\end{array}$ & $\begin{array}{l}1 \mathrm{ml} \\
\text { Perlane Q } \\
\text { Med }\end{array}$ & $\begin{array}{l}\text { A bolus technique with a } 30 \mathrm{G} \\
\text { needle }\end{array}$ & No & $\begin{array}{l}\text { After } 9 \text { months the } \\
\text { correction is still present }\end{array}$ \\
\hline $\begin{array}{l}\text { Ponzo et al. } \\
\text { [28] }\end{array}$ & $\begin{array}{l}\text { Facial } \\
\text { hemiatrophy } \\
\text { of the left } \\
\text { chin and lip }\end{array}$ & $\begin{array}{l}3 \mathrm{ml}, \\
\text { Juvederm } \\
\text { Voluma }\end{array}$ & $\begin{array}{l}\text { ? Partial improvement was } \\
\text { observed }(50 \%)\end{array}$ & $\begin{array}{l}3 \times \mathrm{IPL} \\
\text { after }\end{array}$ & $\begin{array}{l}3.5 \text { years without adverse } \\
\text { effects }\end{array}$ \\
\hline $\begin{array}{l}\text { Sharquie } \\
\text { et al. [23] }\end{array}$ & $\begin{array}{l}16 \text { patients } \\
\text { morphea ( } 1 \\
\text { with en coup } \\
\text { de sabre) }\end{array}$ & $\begin{array}{l}\text { Neauvia } \\
\text { Organic }\end{array}$ & $\begin{array}{l}\text { Two injections, } 1 \text { month apart } \\
\text { in } 10 \text { patients with active } \\
\text { lesion and in } 6 \text { with } \\
\text { nonactive; HA injected deep } \\
\text { into the dermis, including } \\
\text { the scarred area, using a } \\
\text { cannula and a thin needle for } \\
\text { inflammatory lesions }\end{array}$ & No & $\begin{array}{l}\text { Marked response after } \\
2 \text { months; one patient } \\
\text { maintained full correction } \\
\text { after } 4 \text { years }\end{array}$ \\
\hline
\end{tabular}

adverse effects. The outcome in one of the patients persisted for 4 years after the procedure [23].
Of importance, the application of HA produces a temporary, reversible effect; the gel is usually absorbed for 6 months up to 1 year after filling of facial wrinkles. However, "bolus" 
technique may decrease the degradation and prolong the preservation of the filler, which was implemented in patient no. 1, apart from more superficial administration of the gel with a cannula [29]. Additionally, HA establishes a scaffold for newly formed tissue via migration and proliferation of fibroblasts, collagen stimulation and angiogenesis as well as subsequent adipocyte proliferation [29]. What is more, HA acts as an antioxidant and indirectly stimulates neocollagenogenesis (collagen type I and II) together with the production of elastin and extracellular matrix proteins via mechanical stress exerted on the tissue $[30,31]$. Wang et al. have observed fibroblasts to take stretched morphological form and more active phenotype in presence of HA [32].

Moreover, Japanese authors, based on their own experience, encourage the administration of HA with a needle (30 to $34 \mathrm{G}$ ) to stimulate the periosteum. The destruction and the lasting inflammation around the injected HA molecules may activate periosteal stem cells to undergo neo-osteogenesis while $\mathrm{HA}$ is being absorbed [25]. It is necessary to repeat the procedure depending on patient's individual needs; however, with time the demand for correction may become less frequent.

Despite encouraging results, it should be noted that delayed hypersensitivity reactions may occur weeks, months or even years after the procedure. In the course of foreign-body reactions, monocytes and macrophages release inflammatory cytokines, producing multinucleated giant cells, characteristic for granulomas. The reaction aims to isolate and disrupt the migration of an introduced substance, which cannot be removed by enzymatic degradation or phagocytosis [22, 33, 34]. There are a growing number of another types of reactiondelayed $\mathrm{T}$ cell reaction, stimulated by superantigens. In rare cases HA can act as a superantigen [33-35]. Furthermore, Beleznay et al. suggested that the product, subject to natural hyaluronidases, releases low molecular weight $\mathrm{HA}$, which becomes an antigen, thus provoking delayed reactions [36].

Some authors suggest that general and local signs due to reaction to HA are an example of still vaguely characterised ASIA reaction (the autoimmune/inflammatory syndrome induced by adjuvants). HA, as an adjuvant, enhances antigen-specific immune response, induces inflammatory cytokines release and interacts with Toll-like receptors and inflammasome. This reaction leads to innate and adaptive immune response (polyclonal activation of B cells, effect on cellular immunity) and can cause symptoms of autoimmunization and autoimmune disease [37-40]. Solutions of an unknown origin, poorly purified and containing bacterial DNA pose a particular threat [35]. Therefore, the long-term observation and monitoring of the patient as well as the choice of a solution approved by the US Food and Drug Administration (FDA) or European Medicines Agency (EMA) are of the utmost importance.

One of the patients additionally had FAL therapy. As a result of massive furrowing and hyperpigmentation of the lesion in patient no. 3 , fractional ablative $\mathrm{CO}_{2}$ laser therapy was implemented before the administration of HA to improve the coloration and the tension of the skin after first Voluma injection.

FAL therapy significantly improved the final effect in both cases. The isolated columns of ablated skin do not disrupt proper healing and they stimulate collagen remodelling and decrease the level of fibrosis marker transforming growth factor beta-1 (TGF $\beta 1$ ). This therapy leads to the degradation of the abnormal collagen in morphea lesions and the induction of normal collagen synthesis $[15,41]$. The superiority of this method in comparison with low dose UVA-1 was observed in 17 patients in the study by Shalaby et al. [41]. FAL showed statistically significant advantage over UVA-1 in terms of clinical assessment of the lesions (LoSCAT). There was an improvement in collagen homogenization and inflammatory infiltration (histopathological assessment), yet the difference between the groups was not statistically significant. Both methods produced statistically significant decrease in TGF $\beta 1$ and increase in matrix metalloproteinase-1 (MMP1) expression (immunohistochemical evaluation), as well as the reduction of the skin thickness (ultrasound assessment) [41].

The beneficial effects of FAL in morphea may be due to several factors: 
- Induction of production of MMP1, 3, 9 and 13.

- Increase in the expression of heat shock protein 72 around microscopic treatment zones (MTZs) (up to 3 months), which contributes to the activation of epidermal stem cells and dermal cells.

- Ablation of MTZs not only removes part of the homogenized tissue but also relaxes the skin within morphea lesions, improving its texture.

- Hyperpigmentation removal [41-44].

An additional advantage of FAL treatment is the short healing time: epidermis repair occurs within 24 to $48 \mathrm{~h}$. On the other hand, temporarily opened epidermal barrier (TOR) promotes absorption of, among others, medicinal substances [42]. Together with repair processes, approximately $72 \mathrm{~h}$ after the procedure an inflammatory response develops. What is more, it facilitates the removal of coagulated residuals of homogenized collagen, melanin and destroyed keratinocytes, allowing for its replacement with newly synthesized molecules [42].

From our point of view, the combination of HA and FAL therapy produced significantly better aesthetic results than use of one method only. This was confirmed by our patients' satisfaction and clinical assessment (LoSDI-reduction from 5 to 1 ). The combined methods for correction of morphea were also applied by Yeager and Ozog, who used FAL with poly-Llactic acid with very satisfying outcome [14].

In the latest analysis of the literature assessing the current procedure regarding the correction of en coup de sabre and hemiatrophia faciei Parry-Romberg defects, surgical procedures were the most frequent (59\%). Autologous fat grafting was most commonly used as a cosmetic procedure (50\% of procedures), followed by free flap transfers (24\%) [45]. Because the method we applied can be a fast and comparatively painless means for the improvement of the patient's appearance, its popularisation should be given due consideration.

\section{CONCLUSIONS}

Hyaluronic acid fillers are an efficient, minimally invasive therapeutic option for correction of volumetric defects in localized scleroderma in the facial region (hemiatrophia faciei ParryRomberg and en coup de sabre). Moreover, they act via stimulation of production of new, normal connective tissue. The procedure appears to be safe, neither leading to an exacerbation nor reactivation of the disease, and benefits outweigh the risk for the patients. However, the quality of the filler used for the injection is required to be high; therefore, we recommend the use of HA solution approved by the FDA or EMA. Moreover, the procedure needs to be performed by an experienced professional, aware of the risk of adverse effects.

The hyaluronic acid injection can be an effective and safe therapeutic option for patients suffering from morphea, considerably lowering skin damage reflected by reduction in the LoSDI score and enhancing patients' quality of life. In the case of an insufficient effect, fractional ablative $\mathrm{CO}_{2}$ laser may be considered. Because the results are very promising, the method should be further explored in order to confirm its safety and efficacy on a larger experimental group.

\section{ACKNOWLEDGEMENTS}

We thank the participants of the study.

Funding. No funding or sponsorship was received for this study or publication of this article.

Authorship. All named authors meet the International Committee of Medical Journal Editors (ICMJE) criteria for authorship for this article, take responsibility for the integrity of the work as a whole, and have given their approval for this version to be published.

Disclosures. Agnieszka Owczarczyk-Saczonek, Marta Kasprowicz-Furmańczyk, Anna Kruszewska, Magdalena Krajewska-Włodarczyk, 
Agata Bechtold, Paulina Klimek and Waldemar Placek have nothing to disclose.

Compliance with Ethics Guidelines. All subjects provided informed consent before the procedure and agreed to the publication of the results.

Data Availability. Data sharing is not applicable to this article as no datasets were generated or analyzed during the current study.

Open Access. This article is licensed under a Creative Commons Attribution-NonCommercial 4.0 International License, which permits any non-commercial use, sharing, adaptation, distribution and reproduction in any medium or format, as long as you give appropriate credit to the original author(s) and the source, provide a link to the Creative Commons licence, and indicate if changes were made. The images or other third party material in this article are included in the article's Creative Commons licence, unless indicated otherwise in a credit line to the material. If material is not included in the article's Creative Commons licence and your intended use is not permitted by statutory regulation or exceeds the permitted use, you will need to obtain permission directly from the copyright holder. To view a copy of this licence, visit http://creativecommons.org/licenses/by$\mathrm{nc} / 4.0 /$.

\section{REFERENCE}

1. Krasowska D, Rudnicka L, Dańczak-Pazdrowska A, et al. Localized scleroderma (morphea). Diagnostic and therapeutic recommendations of the Polish Dermatological Society. Przegl Dermatol. 2019;106: 4.

2. Budzynska-Wlodarczyk J, Michalska-Jakubus MM, Kowal M, Krasowska D. Evaluation of serum concentrations of the selected cytokines in patients with localized scleroderma. Postep Dermatol Alergol. 2016;33:47.

3. Torok KS, Li SC, Jacobe HM, et al. Immunopathogenesis of pediatric localized scleroderma. Front Immunol. 2019;10:908.
4. Zulian F. New developments in localized scleroderma. Curr Opin Rheumatol. 2008;20:601.

5. Das S, Bernstein I, Jacobe H. Correlates of self-reported quality of life in adults and children with morphea. J Am Acad Dermatol. 2014;70:905.

6. Szramka-Pawlak B, Dańczak-Pazdrowska A, Rzepa T, Szewczyk A, Sadowska-Przytocka A, Żaba R. Quality of life and optimism in patients with morphea. Appl Res Qual Life. 2014;9:863.

7. Zulian F, Culpo R, Sperotto F, et al. Consensusbased recommendations for the management of juvenile localised scleroderma. Ann Rheum Dis. 2019;78:1019.

8. Fett N. Morphea: evidence-based recommendations for treatment. Indian J Dermatol Venereol Leprol. 2012;78:135.

9. Knobler R, Moinzadeh P, Hunzelmann N, et al. European dermatology forum S1-guideline on the diagnosis and treatment of sclerosing diseases of the skin, Part 1: localized scleroderma, systemic sclerosis and overlap syndromes. J Eur Acad Dermatol Venereol. 2017;31:1401.

10. Arsiwala S. Persistence of hyaluronic acid filler for subcutaneous atrophy in a case of circumscribed scleroderma. J Cutan Aesthet Surg. 2015;8:69.

11. Choksi AN, Orringer JS. Linear morphea-induced atrophy treated with hyaluronic acid filler injections. Dermatol Surg. 2011;37:880.

12. Thareja SK, Sadhwani D, Alan Fenske N. En coup de sabre morphea treated with hyaluronic acid filler. Report of a case and review of the literature. Int J Dermatol. 2015;54:823.

13. de Araujo Franco JP, Serra MS, Lima RB, D'Acri AM, Martins CJ. Scleroderma en coup de sabre treated with polymethylmethacrylate-case report. An Bras Dermatol. 2016;91:209.

14. Yeager D, Ozog DM. Persistent improvement at three year follow-up in a patient with localized deep morphea treated with both injected and laser-assisted topical poly-l-lactic acid. Lasers Surg Med. 2019;1:S11.

15. Aksu Arica D. Cosmetical treatments of connective tissue disorders. Dermatol Ther. 2019;32:e12935.

16. Del Papa N, Sambataro D, Zaccara E, et al. SAT0446 autologous fat transplantation has a long term efficacy on scleroderma skin fibrosis: results from a controlled study versus hyaluronic acid filler. Ann Rheum Dis. 2015;1:822. 
17. Onesti MG, Fioramonti $P$, Carella S, Fino $P$, Marchese C, Scuderi N. Improvement of mouth functional disability in systemic sclerosis patients over one year in a trial of fat transplantation versus adipose-derived stromal cells. Stem Cells Int. 2016. https://doi.org/10.1155/2016/2416192.

18. Lafaille P, Benedetto A. Fillers: contraindications, side effects and precautions. J Cutan Aesthet Surg. 2010;3(1):16-9.

19. Kreuter A, Krieg T, Worm M, et al. German guidelines for the diagnosis and therapy of localized scleroderma. J Dtsch Dermatol Ges. 2016;14(2): 199-216.

20. De Boulle K, Heydenrych I. Patient factors influencing dermal filler complications: prevention, assessment, and treatment. Clin Cosmet Investig Dermatol. 2015;8:205.

21. Kogan G, Šoltés L, Stern R, Mendichi R. Hyaluronic acid: a biopolymer with versatile physico-chemical and biological properties. In: Pethrick RA, Ballada A, Zaikov GE, editors. Handbook of polymer research: monomers, oligomers, polymers and composites. New York: Nova Science; 2007.

22. Owczarczyk-Saczonek A, Znajewska-Pander A, Krajewska-Włodarczyk MPW. Lip rejuvenation for a patient with systemic scleroderma. PRIME J. 2017;24-7.

23. Sharquie KE, Fatema A, Al-Jaralla IKS. Intralesional injection of hyaluronic acid as a long lasting therapy of morphea sclerosis. Am J Dermatol Venereol. 2019;8(3):45-8.

24. Callan P, Goodman GJ, Carlisle I, et al. Efficacy and safety of a hyaluronic acid filler in subjects treated for correction of midface volume deficiency: a 24 month study. Clin Cosmet Investig Dermatol. 2013;6:81.

25. Kerdel F, Skopit S. En coup de sabre morphea treated with hyaluronic acid filler while maintained on systemic therapy: a case presentation and discussion. https://cdn.ymaws.com/www.aocd.org/ resource/resmgr/jaocd/contents/volume39/39-09. pdf.

26. Mashiko T, Mori $H$, Kato $H$, et al. Semipermanent volumization by an absorbable filler: onlay injection technique to the bone. Plast Reconstr Surg Glob Open. 2013;1:1.

27. Sivek R, Emer J. Use of a blunt-tipped microcannula for soft tissue filler injection in the treatment of linear scleroderma (en coup de sabre). Dermatol Surg. 2014;40:1439.
28. Ponzo MG, Carruthers A, Humphrey S. Corrective hyaluronic acid fillers and combination cosmetic treatments for facial cutaneous defects due to autoimmune connective tissue diseases: a retrospective review. Dermatol Surg. 2017;43:1510.

29. Mochizuki M, Aoi N, Gonda K, Hirabayashi S, Komuro Y. Evaluation of the in vivo kinetics and biostimulatory effects of subcutaneously injected hyaluronic acid filler. Plast Reconstr Surg. 2018;142: 112.

30. Paliwal S, Fagien S, Sun X, et al. Skin extracellular matrix stimulation following injection of a hyaluronic acid-based dermal filler in a rat model. Plast Reconstr Surg. 2014;134:1224.

31. Sisti A, Boczar D, Restrepo DJ, Nisi G, Forte AJ. Evaluation of the in vivo kinetics and biostimulatory effects of subcutaneously injected hyaluronic acid filler. Plastic Reconstr Surg. 2019;143:659e.

32. Wang F, Garza LA, Kang S, et al. In vivo stimulation of de novo collagen production caused by crosslinked hyaluronic acid dermal filler injections in photodamaged human skin. Arch Dermatol. 2007; 143:155.

33. Alijotas-Reig J, Fernández-Figueras MT, Puig L. Inflammatory, immune-mediated adverse reactions related to soft tissue dermal fillers. Sem Arthr Rheum. 2013;43(2):241-58.

34. Seok J, Hong JY, Park KY, et al. Delayed immunologic complications due to injectable fillers by unlicensed practitioners: our experiences and a review of the literature. Dermatol Ther. 2016;29:41.

35. Bitterman-Deutsch O, Kogan L, Nasser F. Delayed immune mediated adverse effects to hyaluronic acid fillers: report of five cases and review of the literature. Dermatol Rep 2015;7(1).

36. Beleznay K, Carruthers JDA, Carruthers A, Mummert ME, Humphrey S. Delayed-onset nodules secondary to a smooth cohesive $20 \mathrm{mg} / \mathrm{mL}$ hyaluronic acid filler: cause and management. Dermatol Surg. $2015 ; 41: 929$.

37. Owczarczyk-Saczonek A, Wygonowska E, Budkiewicz M, Placek W. Serum sickness disease in a patient with alopecia areata and Meniere' disease after PRP procedure. Dermatol Ther. 2019;32: e12798.

38. Vera-Lastra O, Medina G, Cruz-Dominguez Mdel P, Jara LJ, Shoenfeld Y. Autoimmune/inflammatory syndrome induced by adjuvants (Shoenfeld's syndrome): clinical and immunological spectrum. Expert Rev Clin Immunol. 2013;9:361. 
39. Watad A, Quaresma M, Bragazzi NL, et al. The autoimmune/inflammatory syndrome induced by adjuvants (ASIA)/Shoenfeld's syndrome: descriptive analysis of 300 patients from the international ASIA syndrome registry. Clin Rheumatol. 2018;37:483.

40. Cohen Tervaert JW. Autoinflammatory/autoimmunity syndrome induced by adjuvants (ASIA; Shoenfeld's syndrome): a new flame. Autoimmun Rev. 2018;17(12):1259-64

41. Shalaby SM, Bosseila M, Fawzy MM, Abdel Halim DM, Sayed SS, Allam RSHM. Fractional carbon dioxide laser versus low-dose UVA-1 phototherapy for treatment of localized scleroderma: a clinical and immunohistochemical randomized controlled study. Lasers Med Sci. 2016;31:1707.
42. Helbig D, Paasch U. Molecular changes during skin aging and wound healing after fractional ablative photothermolysis. Ski Res Technol. 2011;17:119.

43. Kineston D, Kwan JM, Uebelhoer NS, Shumaker PR. Use of a fractional ablative $10.6-\mu \mathrm{m}$ carbon dioxide laser in the treatment of a morphea-related contracture. Arch Dermatol. 2011;147:1148.

44. Paasch U. The future of fractional lasers. Facial Plast Surg. 2016;32:261.

45. Glaser DH, Schutt C, Schollaert-Fitch K, Torok K. Linear scleroderma of the head-updates in management of parry romberg syndrome and en coup de sabre: a rapid scoping review across subspecialties. Eur J Rheumatol. 2020;7:S48. 